\title{
Fungicides and alternative products in the mycelial growth and germination control of Alternaria tomatophila
}

\author{
Fungicidas y productos alternativos en el crecimiento micelial \\ y en control de la germinación de Alternaria tomatophila \\ Hugo César Rodrigues Moreira Catão ${ }^{1 *}$, Nilza de Lima Pereira Sales ${ }^{2}$, \\ Daiana Maria Queiroz Azevedo², Nicoletta Stefânia Dias da Silva Flávio², \\ João Batista de Campos Menezes ${ }^{2}$, Letícia Vieira Barbosa ${ }^{1}$, Roberto Antonio Savelli Martinez ${ }^{1}$
}

\begin{abstract}
This study aimed to characterize the in vitro effect of different products on the mycelial growth and conidial germination of Alternaria tomatophila, the etiologic agent of tomato early blight. The experiment was installed using a completely randomized design, in factorial scheme $5 \times 4$, with five levels of concentration $(0 \%, 25 \%, 50 \%, 75 \%$ and $100 \%$ of the commercial recommended doses) $\mathrm{x} 4$ products (cymoxanil + mancozeb, copper oxychloride, potassium phosphite 0-28-26 and biofertilizer) in four replicates . The products were added and homogenized to the PDA mean, to evaluate the inhibition of mycelial growth and incorporated in agar-water mean to test inhibition of conidial germination. The fungicide cymoxanil + mancozeb and the potassium phosphite 0-28-26 were the best evaluated products totally inhibiting the mycelial growth; the copper oxychloride was shown to be intermediary while the biofertilizer was less effective. The products behaved in a similar way in the conidial germination. The fungicide cymoxanil + mancozeb and the phosphite stood out, followed by copper oxychloride and the biofertilizer, however, the products did not completely inhibited the conidial germination of A. tomatophila.
\end{abstract}

Key words: early blight, in vitro control, mycelial growth, conidia, tomato.

\section{RESUMEN}

Este estudio tuvo como objetivo caracterizar el efecto in vitro de diferentes productos en el crecimiento micelial y en la germinación de conidios de Alternaria tomatophila, agente etiológico del tizón temprano del tomate. El experimento se estableció mediante un experimento completamente aleatorizado en un esquema factorial $5 x 4$, con cinco concentraciones $(0 \%, 25 \%, 50 \%, 75 \%$ y $100 \%$ de la dosis comercial recomendada) x 4 productos (cimoxanil + mancozeb, oxicloruro cobre, fosfito de potasio 0-28-26 y biofertilizante) con cuatro repeticiones. Los productos se homogeneizaron y añadieron al medio PDA para evaluar la inhibición del crecimiento micelial y se incorporaron en medio agar-agua para probar la inhibición de la germinación de los conidios. El fungicida mancozeb + cimoxanil y el fosfito de potasio 0-28-26 fueron los mejores productos evaluados inhibiendo totalmente el crecimiento micelial, el oxicloruro de cobre demostró tener un efecto intermedio, mientras el biofertilizante fue menos eficaz. La germinación de conidios tuvo un comportamiento similar frente a los productos evaluados. El fungicida mancozeb + cycomaxil y el fosfito sobresalieron, seguido de oxicloruro de cobre y del biofertilizante; sin embargo, los productos no inhibieron completamente la germinación de esporas de A. tomatophila.

Palabras clave: tizón temprano, control in vitro, conidios, tomate.

\section{Introduction}

The tomato (Solanum lycopersicum L.) has been highlighted as one of the most widely cultivated vegetable crops in Brazil and worldwide (Marim et al., 2005). Brazil is the biggest producer of this vegetable in Latin America and the state of São Paulo the largest consumer market in MERCOSUR and the Southeast, Midwest and Northeast the main centers of production and productivity (Camargo Filho and Mazzei, 2002; Silva and Giordano, 2000). Even though obtaining an expressive production a

\footnotetext{
Universidade Federal de Lavras, UFLA, Lavras, MG, Brasil. Caixa Postal 3037, CEP 37200-000.

2 Universidade Federal de Minas Gerais, Instituto de Ciências Agrárias, UFMG/ICA, Minas Gerais, MG, Brasil.

* Autor para correspondência: hugocatao@yahoo.com.br
}

Fecha de Recepción: 19 Junio, 2012.

Fecha de Aceptación: 10 Junio 2013. 
lot of regions have many difficulties in producing due to the occurrence of pests and diseases affecting the crop creating high.

Among the fungal diseases that affect tomato early blight is one of the most important in that crop and it can attack the plant anywhere and at any age if it find favorable conditions. Although the cause of the disease has been traditionally attributed to the fungus Alternaria solani Sorauer (Rotem, 1994), in 2000 was described a new specie, Alternaria tomatophila Simmons, whose individuals were commonly associated with early blight of tomato (Simmons, 2000). The symptoms manifest with greater intensity in the leaves, reducing plant vigor due to the high rate of defoliation and on the fruits due to depreciation inflicted by the injury of the pathogen. Therefore causes indirect and direct losses (Vale et al., 2000).

The high destructive potential of the disease allowed the use of fungicides to be a key measure for an effective disease control. Alternatives to chemical control are being studied in order to minimize the problems caused by pesticides. The constant search for alternatives in controlling diseases have proposed the development of substances capable of inducing the plant defense system (Kessmann et al., 1995; Leroux, 1996), or have a direct effect on the structures of the pathogens. The use of organic matter both by soil incorporation as by processing for later use has been made viable (Hoitink and Fahy, 1986; Boehm and Hoitink, 1992). The transformation of organic matter via anaerobic fermentation of manure produces an effluent known as biofertilizer. This product is used in foliar spray or applied to the soil, both for nutritional purposes and for the control of diseases and pests. The control of Botrytis cinerea, with aqueous extract from horse cattle and poultry manure's originated compounds, were reported by several authors in beans, lettuce, tomato and pepper (Stindt and Weltzien, 1988; Elad and Shtienberg, 1994; McQuilken et al., 1994).

Another employed control measure has been the use of phosphites in an attempt to practice agriculture with lower pesticide contamination. The phosphites are compounds derived from the neutralization of phosphorous acid $\left(\mathrm{H}_{3} \mathrm{PO}_{3}\right)$, by a base that can be sodium hydroxide, potassium hydroxide, ammonium hydroxide, among others, being the potassium hydroxide the most widely used to form potassium phosphite (Reuveni, 1997). These products are being marketed as fertilizers and they have an effect on the control of various diseases, especially fungal. Despite this technology is presented as emergent, using phosphites have been quite effective in controlling pathogens (Araújo et al., 2010; Nojosa et al., 2009).

The aim of this study was to evaluate the in vitro effect of fungicides (cymoxail + mancozeb and copper oxychloride) and products considered alternatives in controlling diseases (potassium phosphite 0-28-26 and biofertilizer) on mycelial growth and conidial germination of Alternaria tomatophila.

\section{Materials and Methods}

The experiments were performed at the Laboratory of Plant Pathology of the Instituto de Ciências Agrárias of the Universidade Federal de Minas Gerais, in Montes Claros, Minas Gerais State, Brazil. The fungicides were cymoxanil + mancozeb, copper oxychloride, potassium phosphite (0-28-26) and liquid manure biofertilizer. The antifungal activity was evaluated by the fungistatic and fungitoxic effect of the products, by the action on mycelial growth and by the action on the conidia germination of $A$. tomatophila. The monosporic's isolated and the pure cultures of A. tomatophila were obtained from characteristic lesions of early blight on tomato fruits purchased in the region (Alfenas and Mafia, 2007).

For the mycelial growth an evaluation of the experiment was performed using a completely randomized in a $5 \times 4$ factorial scheme, with five concentrations $(0 \%, 25 \%, 50 \%, 75 \%$ and $100 \%$ of the comercial dose of each product) versus 4 products (cymoxanil + mancozeb, copper oxychloride, potassium phosphite 0-28-26 and liquid manure biofertilizer), with 4 replicates, being each petri dish considered a repeat.

The biofertilizer was prepared from the fermentation of fresh manure in an anaerobic system for 40 days. The manure was mixed in equal parts with not chlorinated pure water and placed in a plastic container with a capacity of $200 \mathrm{~L}$, containing a hose attached to the lid to release the methane produced. The dose of biofertilizer was established according to the recommendation proposed by Penteado (2007). This was autoclaved at $121{ }^{\circ} \mathrm{C}$ and $1 \mathrm{~atm}$ for $20 \mathrm{~min}$ prior to addition to the culture medium.

The products were homogenized and added to $100 \mathrm{ml}$ of PDA melting medium, according to 
the concentration to be tested. Then was poured an amount of $20 \mathrm{~mL}$ of each prepared medium in a petri dish with $9 \mathrm{~cm}$ diameter. All plates were inoculated at the center with a mycelial disc of 5 mm diameter with a 7 days old monosporic culture. Funguses grown on PDA without any additions were considered as the only control. The whole procedure was performed under aseptic conditions in a laminar flow hood. The Petri dishes were incubated at $25^{\circ} \mathrm{C}$ under a photoperiod of 12 hours.

To evaluate the effect of the product's concentrations the diameter of the colonies in two orthogonal axes was measured daily (average of two measurements diametrically opposed), starting 24 hours after the inoculation of fungi and for a period of 7 days obtaining the mycelial mean growth per plate (Benício et al., 2003).

The percentage of growth inhibition (PIC) of fungal colonies was determined for each product compared to the control, where:

$$
P I C=\left(\frac{\varnothing \text { control }-\varnothing \text { treatment }}{\varnothing \text { control }}\right) \times 100
$$

$\mathrm{PIC}=$ percentage of growth inhibition, $\varnothing$ control $=$ diameter control, Øtreatment $=$ diameter treatment.

To evaluate the effect of the products on spore germination, conidia suspension of A. tomatophila was placed on water-agar medium containing different products. For that was obtained a pure colony grown for 7 days on V8-agar medium a spore suspension of A. tomatophila at a concentration of $2 \times 10^{5}$ conidia $/ \mathrm{mL}$.

To the doses of each respective product were added $100 \mathrm{~mL}$ of water-agar (20\%). After solidification culture medium blocks were made with a surface area of $2 \mathrm{~cm}^{2}$ and a thickness of $1 \mathrm{~cm}$. Then the blocks were deposited onto a sterilized microscope slides. After that aliquots of $30 \mu \mathrm{L}$ of conidial concentration were placed on the medium and covered with a coverslip. After mounting, the slides were kept in $14 \mathrm{~cm}$ diameter glass plates containing two sheets moistened filter paper with sterile distilled water. The set was stored in incubation chambers BOD at $25^{\circ} \mathrm{C}$ with a photoperiod of 12 hours. The study also was conducted in a completely randomized $5 \times 4$ factorial scheme, similar to the experimental evaluation of mycelial growth, with four replications, each repetition being considered microscope slide with an agar block.
After 18 hour's incubation, $20 \mu \mathrm{L}$ of lactophenol and cotton blue were added to inhibit the germination of conidia and facilitate viewing by optical microscopy. Conidial germination was assessed in two viewing fields of (40X objective) and randomly selected by analyzing 100 conidia per field. Those showing any emission germ tube were considered germinated conidia, regardless of its length (Silva et al., 2009; Tavares and Souza, 2005). The percent inhibition of conidial germination (PIG) was then calculated, where:

$P I G=\left(\frac{\mathrm{n}^{\mathrm{o}} \text { control conidia }-\mathrm{n}^{\mathrm{o}} \text { treatment conidia }}{\mathrm{n}^{\mathrm{o}} \text { control conidia }}\right) \times 100$

PIG $=$ Percent inhibition of conidial germination, $\mathrm{n}^{\mathrm{o}}$ control conidia $=$ control number of conidia, $\mathrm{n}^{\mathrm{o}}$ control treatment $=$ treatment number of conidia.

The data from both trials were subjected to variance analysis, and the means of qualitative data were compared by the Scott-Knott test $(\mathrm{p} \leq 0.01)$ and quantitative data submitted to polynomial regression $(\mathrm{p} \leq 0.01)$.

\section{Results and Discussion}

The products showed differentiated behavior, regarding the following criteria: percentage of mycelial growth inhibition (PIC) and percentage inhibition of conidia germination (PIG). There was significant interaction between the products and the tested concentrations and the polynomial models best suited to describe the behavior of PIC and PIG variables. The fungicides mancozeb + cymoxanil and potassium phosphite were those that promoted the highest percentage of inhibition. Copper oxychloride was shown to be intermediate, while the biofertilizer was the less effective in the in vitro control of A. tomatophila (Tables 1 and 2, Figures 1 and 2).

A significant increase in PIC is observed with increasing concentrations of the tested products, except for the biofertilizer (Figure 1). The fungicide mancozeb + cymoxanil was the product that most inhibited mycelial growth of Alternaria tomatophila and already at a dose of $25 \%$ of the active ingredient ceased in vitro development of the pathogen, followed by phosphite and copper oxychloride. The cymoxanil + mancozeb were recommended only for pathogens such as Phytophthora infestans and mildews. In the followed doses the phosphite was 
Table 1. Mycelial growth inhibition (\%) of Alternaria tomatophila grown on PDA medium for different products and concentrations. Montes Claros, 2010.

\begin{tabular}{lcrrrr}
\hline \multirow{2}{*}{ Product } & \multicolumn{5}{c}{ Concentration (\%) } \\
\cline { 2 - 6 } & 0 & 25 & 50 & 75 & 100 \\
\hline Cymoxanil+mancozeb & $0.0 \mathrm{~A}$ & $93.0 \mathrm{~A}$ & $100.0 \mathrm{~A}$ & $100.0 \mathrm{~A}$ & $95.0 \mathrm{~A}$ \\
Phosphite & $0.0 \mathrm{~A}$ & $84.7 \mathrm{~B}$ & $99.0 \mathrm{~A}$ & $100.0 \mathrm{~A}$ & $99.0 \mathrm{~A}$ \\
Copper oxychloride & $0.0 \mathrm{~A}$ & $67.7 \mathrm{C}$ & $80.0 \mathrm{~B}$ & $83.5 \mathrm{~B}$ & $83.0 \mathrm{~B}$ \\
Biofertilizer & $0.0 \mathrm{~A}$ & $2.0 \mathrm{D}$ & $3.2 \mathrm{D}$ & $5.2 \mathrm{C}$ & $8.3 \mathrm{C}$ \\
CV $(\%)$ & & & 5.55 & & \\
\hline
\end{tabular}

* Means followed by the same letter in the column do not differ by Scott-Knott test at $1 \%$ probability.

statistically equal to cymoxanil + mancozeb and these were superior and different from the other products. Copper oxychloride at a dosage of $100 \%$ of the active ingredient inhibited $83 \%$ growth, while the biofertilizer was less efficient inhibiting only $8 \%$ of the mycelial growth of $A$. tomatophila at its higher concentration.

Products with systemic and protective action such as the fungicide mancozeb + cymoxanil have a higher fungistatic, fungitoxic action and high specificity instead to copper oxychloride. Systemic fungicides action as tebuconazole, difenoconazole, iprodione and fluazinam had superior efficiency in vitro control of $A$. solani, inhibiting more than $80 \%$ from $1 \mu \mathrm{g} / \mathrm{mL}$ and a $100 \%$ of mycelial growth at a dose of $100 \mu \mathrm{g} / \mathrm{mL}$ when compared to products with contact action (Tofoli et al., 2003). That author also states that the fungicides mancozeb and chlorothalonil with a contact action, similar to the action of copper oxychloride, had an intermediate inhibition level, mainly due to its inherent low fungitoxicity.
The action of phosphites has also been observed in other pathosystems. Araújo et al. (2010), demonstrated their direct action on mycelial growth of Colletotrichum gloeosporioides, where a dose of $1.5 \mu \mathrm{L} / \mathrm{mL}$ inhibited significantly the diameter of the colony and reduced the rate of mycelial growth rates.

Similar results have been observed with the use of systemic fungicides and potassium phosphite 0-28-26 in control of plant pathogens in vitro (Araújo et al., 2010; Batista et al., 2002; Tofoli et al., 2003). The use of fungicides and phosphites was also highlighted in the control of postharvest rottenness caused by Penicillium spp., not allowing the growth of mycelium in apple fruits (Brackmann et al., 2005). The potassium phosphite also had a direct effect on mycelial growth of Venturia inaequalis, promoting, using the commercial dose, a reduction of $68.4 \%$ (Boneti and Katsurayama, 2005).

Copper oxychloride was less effective in inhibiting the mycelial growth of early blight,

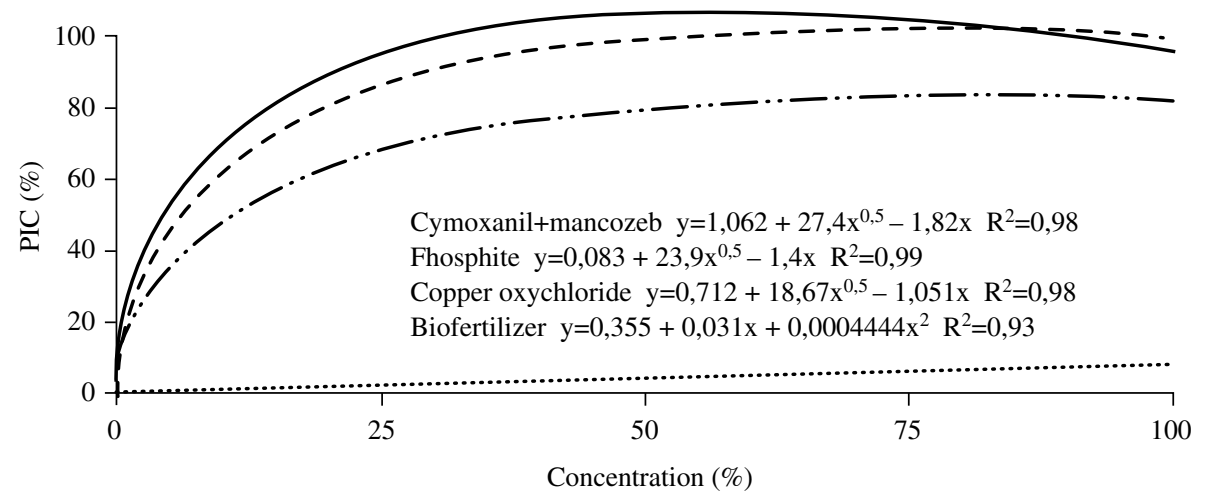

_ Cymoxanil + mancozeb _ - - Fhosphite _ - - - Copper oxychloride $\quad$-.......... Biofertilizer

Figure 1. Mycelial growth inhibition (PIC) for different products and concentrations in in vitro control of Alternaria tomatophila. Montes Claros, 2010. 
diverging from the results presented by Brignani Neto and Oliveira (1980), which indicate the high potential of this product in the inhibitory control of A. solani. Tavares and Souza (2005), evidenced the low efficacy of copper oxychloride on the mycelial growth of Colletotrichum gloeosporioides.

The biofertilizer used in this review did not inhibit mycelial growth of early blight, but there are several examples in the literature demonstrating its effect on pathogenic fungi. Tratch and Bettiol (1997), evidenced that doses above $10 \%$ of biofertilizer supermagro inhibited completely the mycelial growth of various pathogens, including A. solani. The action of biofertilizer originated from anaerobic fermentation of cattle manure was also reported by Carmo and Côrrea (2006) on Colletotrichum gloeosporioides and Uromyces appendiculatus. McQuilken et al. (1994), using an aqueous extract of compost's horse manure and poultry verified the inhibition of mycelial growth and conidial germination of $B$. cinerea, at all ages of extract's extraction.

The aqueous extract of pig manure provided greater inhibition of mycelial growth of Pythium, Phytophthora, Fusarium and Sclerotium (Nakasone et al., 1999). At doses above $30 \%$, the extract inhibited the growth of Pythium on a $100 \%$; On the concentration of $40 \%$ inhibited the development of Phytophthora by $50 \%$, at all tested doses, there was inhibition of Sclerotium, around 50\% and Fusarium less than 50\% (Nakasone et al., 1999).

In this study, the inhibitory effect of the biofertilizer may have declined with autoclaving. Some researches claim that the loss of inhibitory capacity may occur in some cases (Elad and Shtienberg, 1994). In accordance with Hoitink and Fahy (1986) and Hoitink et al. (1997), at temperatures above $60{ }^{\circ} \mathrm{C}$, there is loss of suppressiveness of organic compounds to Pythium spp. and Fusarium spp., besides the elimination of beneficial microorganisms. Visconti et al. (2010), found that aqueous extract of autoclaved organic matter (aqueous extract of bovine manure) did not control the mycelial growth of Cylindrocladium sphathiphylli but an opposite effect occurred stimulating its development. Similar data were observed in this study showing that the biofertilizer of bovine manure was not able to control the in vitro growth of Alternaria tomatophila and also contributed to its development.

The percentage of inhibition of conidial germination (PIG) of A. tomatophila is shown in Table 2 and Figure 2. The effects of the different products on the germination of conidia were similar to those seen in PIC. The cymoxanil + mancozeb and potassium phosphite were the ones which most inhibited germination of conidia, however were statistically different at all doses above $25 \%$. Copper oxychloride had an intermediate action, while the biofertilizer was the least effective.

The fungicide mancozeb + cymoxanil at a concentration of $25 \%$ inhibited the PIG at $88,5 \%$ and in the concentrations above $25 \%$ more than $92 \%$ of the germination. The phosphite, when used at its highest concentration (100\%), inhibited at $76 \%$ the germination of conidia. Copper oxychloride at a concentration of $100 \%$ inhibited $32 \%$ of the conidia. The biofertilizer had the highest inhibition of conidia germination at concentration of $25 \%$.

The cymoxanil + mancozeb showed high levels of inhibition of germination of conidia of A. tomatophila. Tofoli et al. (2003), evaluating the fungicide tebuconazole, difenoconazole, fluazinam, iprodione, among others, found that concentrations above $1 \mu \mathrm{g} / \mathrm{mL}$ inhibited completely the germination of conidia of that fungus. Copper oxychloride showed intermediate levels of inhibition, and increased as the concentration was increased. Contact fungicides, chlorothalonil and mancozeb, evaluated by Tofoli

Table 2. Inhibition of conidial germination (\%) of Alternaria tomatophila for different products and concentrations. Montes Claros, 2010.

\begin{tabular}{lrrrrr}
\hline \multirow{2}{*}{ Product } & \multicolumn{5}{c}{ Concentration (\%) } \\
\cline { 2 - 6 } & 0 & 25 & 50 & 75 & 100 \\
\hline Cymoxanil+mancozeb & $3.50 \mathrm{~A}$ & $88.50 \mathrm{~A}$ & $99.50 \mathrm{~A}$ & $98.90 \mathrm{~A}$ & $92.10 \mathrm{~A}$ \\
Phosphite & $3.50 \mathrm{~A}$ & $54.84 \mathrm{~B}$ & $67.25 \mathrm{~B}$ & $73.35 \mathrm{~B}$ & $76.15 \mathrm{~B}$ \\
Copper oxychloride & $3.50 \mathrm{~A}$ & $9.10 \mathrm{C}$ & $16.75 \mathrm{C}$ & $24.10 \mathrm{C}$ & $32.00 \mathrm{C}$ \\
Biofertilizer & $3.50 \mathrm{~A}$ & $9.30 \mathrm{C}$ & $8.50 \mathrm{D}$ & $6.60 \mathrm{D}$ & $4.10 \mathrm{D}$ \\
CV $(\%)$ & & & 11.83 & & \\
\hline
\end{tabular}

* Means followed by the same letter in the column do not differ by Scott-Knott test at $1 \%$ probability. 


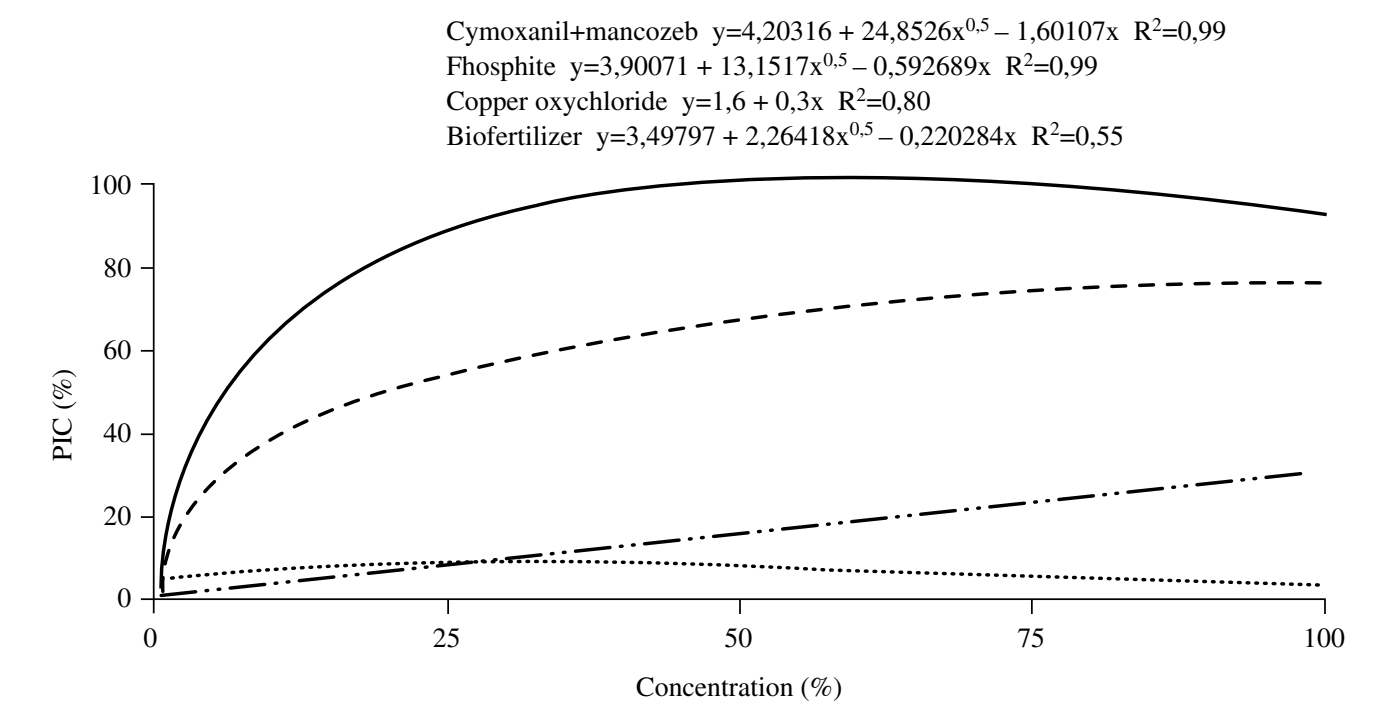

— Cymoxanil + mancozeb $\quad$ - - - Fhosphite $\quad$ - -.. - Copper oxychloride $\quad$........... Biofertilizer

Figure 2. Inhibition percentage of conidial germination (PIG) due to different products in different concentrations in the in vitro control of Alternaria tomatophila. Montes Claros, 2010.

et al. (2003) were intermediate, showing percentages of inhibition of $45-56 \%$ of conidial germination.

When the copper oxychloride was evaluated on the conidia germination effect of Colletotrichum gloeosporioides that fungicide performed better in concentration of $1 \mathrm{ppm}$ with only $10 \%$ of germinated conidia, while systemic action fungicide as azoxystrobin, chlorothalonil, imazalil, propiconazil, tebuconazole, among others, were effective at concentrations above 50 ppm (Tavares and Souza, 2005).

Ribeiro Júnior et al. (2006), testing the direct effect of doses $(0.62 ; 1.25 ; 2.5$ and $5 \mathrm{~mL} / \mathrm{L})$ of potassium phosphite 0-27-27 on conidial germination of Verticillium dahliae, found that all doses showed some toxic effect on conidial germination of Verticillium. A work done by Nojosa et al. (2009) with Phoma costarricensis showed that potassium phosphite reduced the germ tube length by $32 \%$ at doses from 1.5 to $10 \mathrm{~mL} / \mathrm{L}$.

Tratch and Bettiol (1997) found a reduction in the percentage of conidia of $A$. solani, with an increasing concentration of the biofertilizer supermagro. At the concentration of $2.5 \%$, reduced by approximately $50 \%$ the germination of the conidia in relation to the control and, from $10 \%$ the inhibition reached almost $100 \%$ of the germination.

It was verified a higher germination of conidia of Botrytis cinerea when using the biofertilizer supermagro at concentrations of 2.5 and $5 \%$, however, at higher concentrations its total inhibition occurred. In the same work, the autoclaved biofertilizer supermagro proved to be less effective at concentrations of 0.01 to $0.5 \%$ and had effective control over the germination of urediniospores of Hemileia vastatrix and Coelosporium plumierae in doses of 1 and 5\% (Tratch and Bettiol, 1997). In this research, the autoclaved biofertilizer had no effect on the inhibition of conidia of Alternaria tomatophila.

\section{Conclusions}

The active ingredients mancozeb + cymoxanil and potassium phosphite $0-28-26$ were effective in inhibiting the mycelial growth and conidial germination of Alternaria tomatophila. The lowest concentrations of these products, 25 and $50 \%$, allowed total inhibition of the growth of A. tomatophila, while for conidial inhibition higher concentrations were required.

\section{Acknowledgments}

The authors acknowledge the Coordenação de Aperfeiçoamento de Pessoal de Nível Superior CAPES for granting a scholarship to the first author. 


\section{Literature Cited}

Alfenas, A.C. e Mafia, R.G. 2007. Métodos em fitopatologia. Viçosa, MG: UFV, 382 p. Araújo, L.; Valdebenito-Sanhueza, R.M.; Stadnik, M.J. 2010. Avaliação de formulações de fosfito de potássio sobre Colletotrichum gloeosporioides in vitro e no controle pósinfeccional da mancha foliar de Glomerella em macieira. Tropical Plant Pathology, 35 (1): 54-59.

Batista, D.C.; Oliveira, S.M.A.; Tavares, S.C.C.H.; Laranjeira,

D.; Neves, R.A.F. e Silva, R.L.X.

2002. Efeitos de fungicidas sobre o crescimento in vitro de Fusarium oxysporum f. sp. passiflorae e a interferência com Trichoderma spp. Summa Phytopathologica, 28: 305-310.

Benício, V.; Araújo, E.; Souto, F.M.; Benicio, M.J. e Felismino, D.C.

2003. Identificação e características culturais de espécies do gênero Aspergillus isoladas de sementes de feijão no estado da Paraíba. Fitopatologia Brasileira, 28 (2): 180-183.

Boehm, M.J. and Hoitink, H.A.J.

1992. Sustenance of microbial activity in potting mixes and its impact on severity of Pythium root rot of Poinsettia. Phytopathology, 82: 259-264.

Boneti, J.I.S. and Katsurayama, Y.

2005. Viabilidade do uso de fosfitos no controle da sarnada-macieira. Agropecuária Catarinense, Florianópolis, 18 (1): 51-54.

Brackmann, A.; Sestari, I.; Giehl, R.F.H.; Steffens, C.A.; Faulin, G.C. and Pinto, J.A.V.

2005. Controle de podridão pós-colheita de Penicillium spp., em maçã 'Fuji' com fosfitos e fungicidas. Revista Brasileira de Agrociência, Pelotas, 11 (2): 251-254.

Brignani Neto, F. e Oliveira, D.A.

1980. Influência de diferentes fungicidas sobre o crescimento de Alternaria solani (Ell, Martin) Jones, Grout, in vitro. $O$ Biológico, 46 (1): 101-106.

Camargo Filho, W.P. e Mazzei, A.R.

2002. Produção de tomate: sustentabilidade e preços. Informações Econômicas, São Paulo. 32 (8): 45-50.

Carmo, M.G.F. e Côrrea, F.M.

2006. Uso de biofertilizantes no controle de doenças de plantas. In: Venzon, M.; Paula Júnior, T.J.; Pallini, A. (Org.). Tecnologias alternativas para o controle de pragas e doenças. Viçosa: EPAMIG, 2: 103-116.

Elad, Y. and Shtienberg, D.

1994. Effect of compost water extracts on grey mould (Botrytis cinerea). Crop Protection, Guildford. 13 (2): 109-112.

Hoitink, H.A.J. and Fahy, P.C.

1986. Basis for the control of soilborne plant pathogens with composts. Annual Review of Phytopathology, Palo Alto. 24: 93-114.

Hoitink, H.A.J.; Stone, A.G. and Han, D.Y. 1997. Suppression of plant diseases by composts. Hort Science, Alexandria. 32 (2): 184-187.

Kessmann, H.; Ryals, J.; Staub, T.; Oostendorp, M.; Ahl Goy, P.; Hoffmann, C.J.; Friedrich, L.; Delaney, T.; Lawton, K.; Ryals, L.; Weymann, K.; Ligon, H.; Vernoij, B. and Uknes, S.

1995. CGA 245704: Mode of action of a new plant activator. In: International Plant Protection, The Hague The Netherlands, pp. 2-7.
Leroux, P.

1996. Recent developments in the mode action of fungicides. Journal of Pest Science, Heidelberg. 47 (1): 191-197.

Marim, B.G.; Silva, D.J.H.; Guimarães, M.A. e Belfort, G. 2005. Sistemas de tutoramento e condução do tomateiro visando produção de frutos para consumo in natura. Horticultura Brasileira, Brasília, DF. 23 (4): 951-955.

McQuilken, M.P.; Whipps, J.M. and Lynch, J.M.

1994. Effects of water extracts of a composted manure-straw mixture on the plant pathogen Botrytis cinerea. World Journal of Microbiology \& Biotechnology, Oxford. 10 (1): 20-26.

Nakasone, A.K.; Bettiol, W. e Souza, R.M.

1999. Efeito de extratos aquosos de matéria orgânica sobre fitopatógenos. Summa Phytopathologica, Jaboticabal. 25: 330-335.

Nojosa, G.B.A.; Resende, M.L.V.; Barguil, B.M.; Moraes,

S.R.G. e Vilas Boas, C.H.

2009. Efeito de indutores de resistência em cafeeiro contra mancha de Phoma. Summa Phytopathologica. 35 (1): 60-62.

Penteado, S.R.

2007. Adubação na agricultura ecológica. Viçosa, MG: Via Orgânica, 154 p.

Reuveni, M.

1997. Post-infection aplications of $\mathrm{K}_{3} \mathrm{PO}_{3}$, phosphorous acid and Dimethomorph inhibit development of Downy mildew caused by Plasmopara viticola on grapes. Journal of Small Fruit \& Viticulture, Binghamton. 5 (2): 27-38.

Ribeiro Júnior, P.M.; Resende, M.L.V.; Pereira, R. B.; Cavalcanti,

F.R.; Amaral, D.R. e Pádua, M.A.

2006. Fosfito de potássio na indução de resistência a Verticillium dahliae Kleb. em mudas de cacaueiro (Theobroma cacao L.). Ciência e Agrotecnologia, Lavras. 30 (4): 629-636.

Rotem, J.

1994. The genus alternaria: biology, epidemiology, and pathogenicity. Saint Paul: APS, 326 p.

Silva, A.C.; Sales, N.L.P.; Araújo, A.V. e Caldeira Júnior, C.F. 2009. Efeito in vitro de compostos de plantas sobre o fungo Colletotrichum gloeosporioides penz. isolado do maracujazeiro. Ciência e Agrotecnologia. 33: 1853-1860.

Silva, J.B.C. and Giordano, L.B.

2000. Tomate para processamento industrial. Brasília: EMBRAPA Hortaliças, 168 p.

Simmons, E.G.

2000. Alternaria themes and variations (244-286) species on Solanaceae. Mycotaxon, Ithaca. 75: 1-15.

Stindt, A. and Weltzien, H.C.

1988. Der einfluss von waessringen, mikrobiologish activen extrakten von kompostiertem organischen. MededelingerFaculteit, Landbouwwetenschappen Rijksuniversiteit Gent. 53(2): 379-388.

Tavares, G.M. e Souza, P.E.

2005. Efeito de fungicidas no controle in vitro de Colletotrichum gloeosporioides, agente etiológico da antracnose do mamoeiro (Carica papay L.). Ciência e Agrotecnologia, Lavras. 29 (1): 52-59.

Tofoli, J.G.; Domingues, R.J.; Garcia-Junior, O. e Kurozawa, C. 2003. Controle da pinta preta por fungicidas e seus impactos na produção. Summa Phytopathologica. 29 (3): 225-233. 
Tratch, R. e Bettiol, W.

1997. Efeito de biofertilizante sobre o crescimento micelial e a germinação de esporos de alguns fungos fitopatogênicos. Pesquisa Agropecuária Brasileira, Brasília, DF. 32: 1131-1139. Vale, F.X.R.; Zambolim, L.; Paul, P.A. e Costa, H. 2000. Doenças causadas por fungos em tomate. In: Zambolim, L.; Vale, F.X.R.; Costa, H. (Ed.). 2000 Controle de doenças de plantas: hortaliças. Viçosa, MG: UFV, $756 \mathrm{p}$.
Visconti, A; Bettiol, W. e Morandi, M.A.B.

2010. Efeito de hidrolisado de peixe sobre o crescimento micelial e controle de Cylindrocladium spathiphylli em espatifilo. Summa Phytopathologica. 36: 298-308. 